\title{
THE POLITICS OF LANGUAGE POLICIES: HUNGARIAN LINGUISTIC MINORITIES IN CENTRAL EUROPE
}

ABSTRACT The paper will adopt the position that language is an intrinsic and largely non-negotiable part of individual culture and identity. The recognition of one's own language receives more and more support in international political and institutional frameworks. The promotion of linguistic diversity is the official policy of the European Union. Due to such policies, it is to be expected that languages will remain in contact in the context of all sorts of levels of governance. In order to manage linguistic diversity in multilingual and multicultural areas, the introduction of a global regime of language policies is unavoidable. These policies will need to satisfy transnational requirements and conditions, like universal human rights and the norms and standards of Europeanization set by the EU, OSCE, Council of Europe, and so on. However, because there are manifold connections between language and power, as we know from the work of political scientists such as Pierre Bourdieu, and sociolinguists such as Peter Nelde, that a language element is always a part of intergroup conflict. Hence, it is to be expected that language policies will be subject to power conflicts and hegemonic strives. In order to support my claim, I will analyze the language policies of states with Hungarian language minorities in Central Europe, particularly Romania, Slovakia, Serbia (Vojvodina), and Ukraine (Trans-Carpathia). The policies can be studied in terms of concrete variables, like individual/collective rights, territorial rearrangements, thresholds, the Language Charter, multilingual education, the linguistic landscape, and so on. The range in which these variables are instantiated is determined by local politics; hence, it is a case of the politics of language policy.

Key words: multilingualism, politics of diversity, language policy, Hungarian language minorities, Central Europe 


\section{HUNGARIAN MINORITY LANGUAGES}

\subsection{Hungarian in the Carpathian Macroregion}

In 1867 , the Hungarian kingdom became an autonomous entity within the Habsburg Empire. As a consequence, the Hungarian language became an official state language and also functioned as a language of regional communication. In the Hungarian parts of the Habsburg Empire, the Nationality Law XLIV (1868) resulted into a hierarchy of the regional languages of communication stipulating that Hungarian is the language of the state, but it did allow the use of any other (regional) vernacular language as an official language at the local level, including governmental administration, judiciary, church organizations, and education. ${ }^{1}$ This state of affairs lasted until the collapse of the Austro-Hungarian Empire at the end of the First World War.

Due to the peace treaties ending the First World War, including the Treaty of Trianon (1920), ${ }^{2}$ the Hungarian language functioned as the state language in the truncated kingdom of Hungary, while it received a minority status in the newly established states of Central and Eastern Europe, i.e. Czechoslovakia, Romania, Yugoslavia, and Austria. Due to the nationalist climate of the Interwar period, the borders in Central Europe were closed. Hence, the Hungarian language remained a local vernacular language in all areas outside Hungary, being formally granted a minority status. ${ }^{3}$ However, even these minority language rights were hardly realized in practice. Because of the fact that Czechoslovakia seceded its easternmost parts to Soviet Ukraine, a Hungarian ethnic minority came into existence in Ukraine after the Second World War. The situation characterized by isolation in the Interwar period remained more or less unchanged during the Cold War. Only at the end of the Soviet period cross-border traffic increased, and the Hungarian language started to develop into a regional vernacular language.

Due to the collapse of communism and the new state formation in Central and Eastern Europe, ethnic Hungarians have come to live in eight different countries in

The research leading to these results has received funding from the European Union's Seventh Framework Programme (FP7/2007-2013) under grant agreement no. 613344. See R. Bideleux, I. Jeffries, A History of Eastern Europe. Crisis and Change, London 1998; L. Marácz, 'Multilingualism in the Hungarian Kingdom (1867-1918): Language Policy and Practice' in J. Róka (ed.), Concepts \& Consequences of Multilingualism in Europe, Budapest 2010, pp. 55-96; and S. Gal, 'Polyglot Nationalism. Alternative Perspectives on Language in $19^{\text {th }}$ Century Hungary', Langage et Société, Vol. 2, No. 136 (2011), pp. 1-24, at <http://dx.doi.org/10.3917/ls.136.0031>.

2 Compare P. Teleki, The Evolution of Hungary and its Place in European History, New York 1923; E. Chaszar, 'Trianon and the Problem of National Minorities' in B.K. Király, P. Pastor, I. Sanders (eds.), Essays on World War I. Total War and Peacemaking, a Case Study on Trianon, New York 1982, pp. 479-491 (War and Society in East Central Europe, 6. East European Monographs, 105. Atlantic Studies, 15); D.P. Hupchick, H.E. Cox, The Palgrave Concise Historical Atlas of Eastern Europe, New York 2001; E. Goldstein, The First World War Peace Settlements, 1919-1925, London 2002, pp. 31-33 (Seminar Studies in History); and I. Bowman, The New World. Problems in Political Geography, London 1923.

3 See P.H. van der Plank, Etnische zuivering in Midden-Europa. Natievorming en Staatsburgerschap in de XXe eeuw, Leeuwarden 2004 (Acta Launiana, 2). 
Central and Eastern Europe, including the Republic of Hungary $(10,558,001)$, Romania $(1,604,266)$, Serbia $(339,491)$, Croatia $(22,355)$, Slovenia $(7,637)$, Austria $(6,763)$, Slovakia $(567,296)$ and Ukraine $(155,711) \cdot{ }^{4}$ Compare the following table based on the census data of 1991:

Table 1. Ethnic Hungarians in the states of the Carpathian Macroregion

\begin{tabular}{|c|c|}
\hline State & Number \\
\hline Hungary & $10,558,001$ \\
\hline Slovakia & 567,296 \\
\hline Ukraine & 155,711 \\
\hline Romania & $1,604,266$ \\
\hline Serbia (Vojvodina) & 339,491 \\
\hline Croatia & 22,355 \\
\hline Slovenia & 7,637 \\
\hline Austria & 6,763 \\
\hline Total & $13,261,520$ \\
\hline
\end{tabular}

Source: K. Kocsis, E. Kocsis-Hodosi, Hungarian Minorities in the Carpathian Basin. A Study in Ethnic Geography, Toronto-Buffalo 1995, p. 17.

It is worth remembering that ethnic Hungarians who live in all these states are autochthonous inhabitants of the region. At present, the former Hungarian parts of the Austro-Hungarian Empire match with the so-called Carpathian Macroregion that is being surrounded by the Carpathian Mountains. ${ }^{5}$ This region is defined by specific geographical, common socio-cultural, ecological and linguistic features. ${ }^{6}$ It has been

4 Compare L. Marácz, 'Guarding the Hungarian Language and Identity in the New Europe: "The Nation Lives in Its Language" in idem (ed.), Expanding European Unity. Central and Eastern Europe, Amsterdam 1999, pp. 69-91 (Yearbook of European Studies, 11); P.H. van der Plank, Etnische zuivering...; A. Fenyvesi (ed.), Hungarian Language Contact Outside Hungary. Studies on Hungarian as a Minority Language, Amsterdam 2005 (Impact: Studies in Language and Society, 20); and S. Gal, 'Hungarian as a Minority Language' in G. Extra, D. Gorter (eds.), Multilingual Europe. Facts and Policies, Berlin 2008, pp. 207-232 (Contributions to the Sociology of Language, 96).

$5 \quad$ P. Teleki, The Evolution of Hungary...; and L. Marácz, "Will Hungarian Become a Lingua Franca in the Carpathian Basin?' in B. Bodó, M. Tonk (eds.), European Union, Nations and National Minorities, Cluj-Napoca 2009, pp. 117-118.

6 The World Wildlife Fund (WWF) has given a special status to the region of the Carpathian Mountains which is a territory with a specific biodiversity in Central and Eastern Europe (see website: <http://wwf.panda.org/what_we_do/where_we_work/black_sea_basin/danube_carpathian/>, 9 June 2012). In 1998, the WWF founded the Carpathian EcoRegion Initiative (CERI) that is an international coalition of NGOs and research institutes working towards a common vision and sustainable developments in the territory of the Carpathian Mountains. The CERI includes the Carpathian regions of seven different countries including the Czech Republic, Hungary, Poland, Romania, Serbia, Slovakia and Ukraine (see website: <www.carpates.org>, 9 June 2012). 
observed that there is a characteristic geo-ethno-linguistic distribution and diversity of the languages spoken in the Carpathian Macroregion. In Table 2, the most important ethno-linguistic groups are listed based on the census data of $2001 .^{7}$

Table 2. Geo-ethno-linguistic distribution in the Carpathian Macroregion

\begin{tabular}{|c|c|c|}
\hline Group & Number & Percentage \\
\hline Hungarians & $11,706,000$ & 39.7 \\
\hline Romanians & $5,464,000$ & 18.5 \\
\hline Slovaks & $4,716,000$ & 16.0 \\
\hline Croats & $2,828,000$ & 9.6 \\
\hline Serbs & $1,497,000$ & 5.1 \\
\hline Russians/Ukrainians & $1,125,000$ & 3.8 \\
\hline Roma & 579,000 & 2.0 \\
\hline Germans & 372,000 & 1.3 \\
\hline Slovenes & 82,000 & 0.3 \\
\hline Czechs & 60,000 & 0.2 \\
\hline Montenegrins & 38,000 & 0.1 \\
\hline Russians & 33,000 & 0.1 \\
\hline Bosniaks & 27,000 & 0.1 \\
\hline Others & 105,000 & 0.4 \\
\hline Unknown & 828,000 & 2.8 \\
\hline
\end{tabular}

Source: K. Kocsis, Z. Bottlik, P. Tátrai, Etnikai térfolyamatok a Kárpát-medence határainkon túli régióiban (1989-2002), Budapest 2006, p. 28 (Elmélet, Módszer, Gyakorlat, 61).

Table 2 demonstrates that the biggest ethno-linguistic group in the Carpathian Macroregion is the ethnic Hungarians, i.e. ethnic Hungarians have a relative majority of almost forty percent.

It has been noted that there is a strong correlation between ethnicity and the mother-tongue or L1 spoken in this region. ${ }^{8}$ The L1 of ethnic Hungarians in the Carpathian Macroregion is Hungarian; the L1 of ethnic Romanians is Romanian, and so forth. However, the reverse of this correlation does not have to be true. An L1-speaker of Hungarian can be a person of non-Hungarian ethnicity.

Compare K. Kocsis, Z. Bottlik, P. Tátrai, Etnikai térfolyamatok a Kárpát-medence határainkon túli régióiban (1989-2002), Budapest 2006, p. 28 (Elmélet, Módszer, Gyakorlat, 61).

8 Compare A.D. Smith, National Identity, London 1991 (Penguin Politics and Current Affairs); R. Brubaker et al., Nationalist Politics and Everyday Ethnicity in a Transylvanian Town, Princeton 2006; L. Marácz, 'Will Hungarian Become..., pp. 117-141; and idem, 'European Tools of Conflict Management in Central European States with Hungarian Minorities', Kommunikáció, Média, Gazdaság, Vol. 8, No. 1 (2010), pp. 77-116. 
The following table based on the census data of 2001 presents the distribution of the ethnic Hungarians living in the Carpathian Macroregion in eight different states. The corresponding percentages including ethnic Hungarian minority groups in eight different states are spelled out in Table 3 as well:

Table 3. Geo-ethno-linguistic distribution in the states of the Carpathian Macroregion

\begin{tabular}{|c|c|c|}
\hline Territory & $\begin{array}{c}\text { Percentage of state } \\
\text { nationality }\end{array}$ & $\begin{array}{c}\text { Percentage of national } \\
\text { minorities }\end{array}$ \\
\hline Hungary & 91.2 & 1.3 \\
\hline Slovakia & 85.5 & 11.5 \\
\hline Sub-Carpathia (Ukraine) & 80.5 & 18.3 \\
\hline Transylvania (Romania) & 74.6 & 23.8 \\
\hline Vojvodina (Serbia) & 65.0 & 26.7 \\
\hline Pannonian/Slavonian Croatia & 90.1 & 7.7 \\
\hline Muraregion (Slovenia) & 85.0 & 9.5 \\
\hline Burgenland (Austria) & 87.4 & 12.5 \\
\hline Carpathian Macroregion & 83.7 & 11.5 \\
\hline
\end{tabular}

Source: K. Kocsis, Z. Bottlik, P. Tátrai, Etnikai térfolyamatok a Kárpát-medence határainkon túli régióiban (1989-2002), Budapest 2006, p. 29 (Elmélet, Módszer, Gyakorlat, 61).

From Table 3 it follows that most of the ethnic Hungarians live in the Republic of Hungary where they constitute more than ninety percent of the population. ${ }^{10}$ In the other seven countries ethnic Hungarians form numeric minorities which have legal minority rights. However, they do not enjoy equal rights to the majority nation. The use of the minority language is severely restricted compared to the majority vernaculars, i.e. the languages of the state in the official domains. ${ }^{11}$

\subsection{Multilingual regions with Hungarian minorities}

Ethno-linguistic Hungarian communities live mostly in compact territories bordering the Hungarian kin-state. ${ }^{12}$ In Slovakia, almost the entire ethno-linguistic Hungarian

9 See K. Kocsis, E. Kocsis-Hodosi, Hungarian Minorities in the Carpathian Basin. A Study in Ethnic Geography, Toronto-Buffalo 1995, p. 17.

10 See Á. Tóth, National and Ethnic Minorities in Hungary, 1920-2001, trans. by N. Arato, Boulder 2005 (East European Monographs, 698. Atlantic Studies on Society in Change, 124).

11 Compare M. Kontra, H. Hattyár (eds.), Magyarokés nyelvtörvények, Budapest 2002 (Magyarságkutatás Könyvtára, 26); and O. Nádor, L. Szarka (eds.), Nyelvi jogok, kisebbségek, nyelvpolitika Kelet-Közép-Európában, Budapest 2003 (Magyar Kisebbségi Könyvtár).

12 Consider G. Schöpflin, Hungary and its Neighbours, Paris 1993 (Chaillot Papers, 7); J. Tóth, 'Kin Minority, Kin-state and Neighbourhood Policy in the Enlarged Europe', Central European Political Science Review, No. 17 (2004), pp. 14-25; M.M. Kovács, J. Tóth, 'Kin-state Responsibility and Ethnic 
group lives in the southern parts of the country in a stroke of thirty kilometers along the border with Hungary which is 681 kilometers long. ${ }^{13}$ Although the ethnic Hungarians form a substantial group in Slovakia, counting 560,000 people which constitute more than ten percent of Slovakia's overall population, their geographic distribution is rather complex. The ethnic Hungarians do not always have an absolute or even relative majority in the areas they live in. In the Sub-Carpathian region (or Trans-Carpathian region seen from Ukraine's perspective), the ethnic Hungarian communities are located along the Ukrainian-Hungarian border. ${ }^{14}$ In Romania, most of the ethnic Hungarians live in the northwestern part of the country, i.e. Transylvania, which is a traditional multi-ethnic, multilingual region. ${ }^{15}$ In fact, the Hungarian minority in Transylvania lives in the northern part of the area, stretching from the Hungarian-Romanian border to the Szeklerland at the feet of the Eastern Carpathians Mountains, deep into the centre of present-day Romania. ${ }^{16}$ In Serbia, the Hungarians live in the northern part of the country, i.e. Vojvodina. ${ }^{17}$ In Croatia, the ethnic Hungarian community lives in the Slavonian or Pannonian part of the country. ${ }^{18}$ In Slovenia, the ethnic Hungarian community lives in the Mura Region, and in Austria the Hungarians live in Burgenland. ${ }^{19}$ Due to the fact that in these ethnic areas outside Hungary the official language of the states involved, i.e. Slovak, Ukrainian, Romanian, Serbian, Croatian, Slovene, and German, is used next to the Hungarian language, these areas are multilingual. In fact, all Hungar-

Citizenship: The Hungarian Case' in R. Bauböck et al. (eds.), Acquisition and Loss of Nationality, Vol. 1: Comparative Analyses, Amsterdam 2009, pp. 151-176 (IMISCOE Research); A. Batory, 'Kin-state Identity in the European Context: Citizenship, Nationalism and Constitutionalism in Hungary', Nations and Nationalism, Vol. 16, No. 1 (2010), pp. 31-48, at <http://dx.doi.org/10.1111/ j.1469-8129.2010.00433.x>; and L. Marácz, 'European Tools..., pp. 77-116.

13 See G. Szabómihály, 'A szlovákiai kisebbségek nyelvi jogai és a kisebbségi nyelvhasználat színterei, különös tekintettel a magyar közösségre’ in O. Nádor, L. Szarka (eds.), Nyelvi jogok..., pp. 95-110.

${ }^{\text {Sec }}$ A. Beregszászi, I. Csernicskó, 'A magyar nyelv használatának lehetőségei Kárpátalján de jure és de facto' in O. Nádor, L. Szarka (eds.), Nyelvi jogok..., pp. 110-123.

14 See A. Beregszászi, I. Csernicskó, 'A magyar nyelv használatának lehetőségei Kárpátalján de jure és de facto’ in O. Nádor, L. Szarka (eds.), Nyelvi jogok..., pp. 110-123.

15 Compare J.F. Cadzow, A. Ludanyi, L.J. Elteto (eds.), Transylvania. The Roots of Ethnic Conflict, Kent 1983; K. Kocsis (ed.), South Eastern Europe in Maps, Budapest 2005; J. Péntek, A. Benő, 'Nyelvi jogok Romániában' in O. Nádor, L. Szarka (eds.), Nyelvi jogok..., pp. 123-148; and J. Péntek, 'Magyar nyelv, magyar nyelvhasználat Kolozsváron’ in A. Benő, S.N. Szilágyi (eds.), Nyelvi közösségek - nyelvi jogok, Kolozsvár 2006, pp. 267-273 (Szabó T. Attila Nyelvi Intézet Kiadványai, 3). G. Schöpflin, Hungary...,

17 See T. Korhecz, 'A hivatalos nyelvhasználat jogi keretei a Vajdaságban - Szerbiában - jog és gyakorlat', Magyar Tudomány, Vol. 11 (2009), pp. 1313-1321.

18 See K. Lábadi, 'Nyelvtörvények, nyelvi jogok Horvátországban’ in O. Nádor, L. Szarka (eds.), Nyelvi jogok..., pp. 176-190.

19 L. Szarka, 'Államnyelv, hivatalos nyelv - kisebbségi jogok Kelet-Közép-Európában’ in O. Nádor, L. Szarka (eds.), Nyelvi jogok..., pp. 15-37; A. Kolláth, 'A szlovéniai kisebbségek nyelvi jogai - különös tekintettel a magyar kisebbségre' in O. Nádor, L. Szarka (eds.), Nyelvi jogok..., pp. 190-204; and S. Szoták, 'Az ausztriai kisebbségek nyelvi jogai - különös tekintettel a magyar kisebbségekre' in O. Nádor, L. Szarka (eds.), Nyelvi jogok..., pp. 204-219. 
ian speakers are plurilingual speakers, controlling the local Hungarian vernacular and the official language of the state they are citizens of. ${ }^{20}$

The most important factors governing multilingual and transnational communication in the regions with ethnic Hungarian minorities are the historical and traditional customs, the role of borders and language policy. Let us discuss first the historical pattern of two types of multilingual and transnational communication.

These two types are opposing each other, including real multilingual or plurilingual communication and separate multilingualism. In the former type, non L1-speakers share each other's language. This is illustrated by the communication traditions in Vojvodina. This region in the southern part of the Austro-Hungarian Empire received an autonomous status within the Austro-Hungarian Empire, and again during the twentieth century in the former Yugoslav republic. In Vojvodina, traditionally six languages are spoken, including Serbian, Hungarian, Slovak, Romanian, Croatian and Ruthenian. Furthermore, there is a tradition for ethnic groups to speak each other's languages, or to use a mode of communication called intercomprehension, when both interlocutors speak their $\mathrm{L} 1$ and at the same time are able to understand each other's languages. ${ }^{21}$ However, the tradition of multilingual and transnational communication in the region of Transylvania differs from the one in Vojvodina.. In Transylvania, traditionally three languages are spoken, i.e. Hungarian, Romanian and German. The German variant is a Saxon dialect that was brought to Transylvania in the early Middle Ages by the German settlers from the Mosel area. Here, in this region, multilingualism has traditionally been a case of "separate" or parallel monolingualism where the three language communities hardly spoke each other's languages. ${ }^{22}$ With the exception of the civic and ecclesial regional elite, most of the inhabitants of Transylvania have displayed a monolingual attitude. ${ }^{23}$ Separate multilingualism was further strengthened due to the hegemonic relations between the languages involved. Before the First World War Hungarian was the official language in the Hungarian part of the Austro-Hungarian Empire, to which Transylvania also belonged. Standard German also had an important role because it functioned as the lingua franca in the Austro-Hungarian Empire ${ }^{24}$, while Romanian did not receive an official status on the national level but only at the community or regional level. ${ }^{25} \mathrm{~A}$ minimum of twenty percent of the speakers had to be speakers of a regional vernacular language in order for that language to be recognized as an official language in the administrative and territorial domains. Although in the Habsburg Empire multilingualism was recognized as a positive value, the monolingual attitude became the prevailing one, supported by a nationalist

20 A. Fenyvesi (ed.), Hungarian Language...,

21 See G. Korshunova, L. Marácz, 'Multilingualism and Transnational Communication Strategies in Europe: From Hapsburg to the European Union' in L. Marácz, M. Rosello (eds.), Multilingual Europe..., pp. 57-79.

22 See L. Marácz, 'Multilingualism in the Hungarian Kingdom..., pp. 55-96.

23 See S. Gal, 'Polyglot Nationalism..., pp. 1-24

24 See Rindler Schjerve (ed.), Diglossia and Power. Language Policies and Practice in the $19^{\text {th }}$ Century Habsburg Empire, Berlin 2003 (Language, Power and Social Process, 9).

25 L. Marácz, 'Multilingualism in the Hungarian Kingdom...', pp. 55-96. 
language policy. In Transylvania, multilingualism came to be characterized by an asymmetry, as L1-speakers of Hungarian mostly also speak Romanian, but there are hardly any L1-speakers of Romanian that speak Hungarian. ${ }^{26}$ The nation-states in the twenty first century manage their multilingual regions with language policies that are dominated by a monolingual attitude. The hegemonic language, i.e. the official language of the state, is often promoted at the expense of so-called minority languages. ${ }^{27}$ An exceptional case in the Carpathian Macroregion is the recent language policy of the Autonomous Province (AP) of Vojvodina that can be qualified as "multilingual".

Hence, the Hungarian language in the states with Hungarian minorities has a limited distribution restricted to the areas where the ethnic Hungarians live. These regions, including southern Slovakia, Subcarpathia, Transylvania, Vojvodina, Pannonian/Slavonian Croatia, the Mura Region and Burgenland, are traditionally mixed, multilingual areas where, next to the language of the state, i.e. Slovak, Ukrainian/Ruthenian, Romanian, Serbian, Croatian, Slovene and German, one encounters especially Hungarian and the languages of various smaller linguistic minorities.

\subsection{Multilingual and transnational communication in regions with Hungarian minorities}

The linguistic situation is not the same in all of these subregions in the Carpathian Macroregion discussed above. Different factors guide the multilingual and transnational communication in these regions. In this paper, we will adopt Vertovec's concept of "transnationalism". In Vertovec's work, transnationalism is studied in detail in the context of globalization. ${ }^{28}$ According to Vertovec, transnationalism, or sustained cross-border relationships, are patterns of exchange, affiliations and social formations spanning nation-states. ${ }^{29}$ When referring to sustained linkages and ongoing exchanges among non-state actors based across national borders - business, non-government-organizations, and individuals sharing the same interests - we can differentiate these as "transnational". In fact, transnational relations do not only appear in the case of spanning nation-states but they appear also in the case of national or social communities speaking different languages. ${ }^{30}$ Hence, the border between the communities does not need to be an actual territorial border, it can also be a virtual one.

Janssens, Mamadouh and Marácz ${ }^{31}$ distinguish two vectors in order to classify languages of communication, i.e. firstly the scope of communication that can be local, re-

26 R. Brubaker et al., Nationalist Politics...

27 R. Rindler Schjerve, E. Vetter, European Multilingualism. Current Perspectives and Challenges, Bristol 2012, pp. 139 (Second Language Acquisition, 147).

28 S. Vertovec, Transnationalism, New York 2010 (Key Ideas).

29 Ibid., p. 2.

30 Ibid, p. 3.

31 R. Janssens, V. Mamadouh, L. Marácz, 'Languages of Regional Communication (ReLan) in Europe: Three Case Studies and a Research Agenda' in J. Normann Jorgensen (ed.), A Toolkit for Transnational Communication in Europe, Copenhagen 2011 (Copenhagen Studies in Bilingualism, 64). 
gional or global, and secondly the language abilities of the interlocutors participating in the communicative event, i.e. mother-tongue (L1) or foreign language speakers (L2). If only L2-speakers are involved in the communicative event and they share the same language, we refer to a regional lingua franca. This results in the following language constellation from the perspective of the Hungarian speakers in the Carpathian Macroregion. Hungarian is a "transnational regional vernacular" in a wider region: L1-speakers in Hungary, Slovenia, Austria, Slovakia, Ukraine, Romania, Serbia and Croatia. The Hungarian language is used by Hungarian minority speakers in order to communicate with Hungarian speakers from Hungary and with other Hungarian minorities in Central and East European states. However, Hungarian minority speakers, being plurilingual, use the official state language to communicate with the authorities and L1-speakers of the Slovak, Romanian and other state languages. L1-speakers of the state languages display a monolingual attitude. ${ }^{32}$ It is worth noting that this asymmetric relation is a source of conflict. The language of the majority is more powerful than the one spoken by the minorities, and in some countries their language is excluded from the official and public domain. On the other hand, there are a number of non-Hungarian L1-speakers who have developed a receptive competence of Hungarian in the Carpathian Macroregion. Hence, it is expected that the use of communication modes, such as "intercomprehension" or "code-switching", will be more frequent. As a consequence, the position of Hungarian as a regional vehicular language is becoming stronger in the Carpathian Macroregion, resulting in increasing multilingualism. ${ }^{33}$

\section{LANGUAGE POLICIES IN THE CARPATHIAN MACROREGION}

In the twentieth century, the language policies towards ethnic and national minorities depended on several different factors. The European nation-states pursued a policy of monolingualism in which the official language of the state enjoyed a stronger, i.e. hegemonic position, than other smaller "minority" languages. ${ }^{34}$ This was also the case in all the states of the Carpathian Macroregion, maybe with the exception of former Yugoslavia's Vojvodina, although the position of the Serbo-Croatian lingua franca was clearly promoted across the board, especially in territories where a number of linguistic minorities lived together, like in Vojvodina. ${ }^{35}$ In the period after the collapse of communism, a further fragmentation of the system of states in the Carpathian Macroregion took place. The Hungarian minorities came to live in seven states, including Slovakia, Romania, Ukraine, Austria, Slovenia, Croatia and Serbia. The language policy with re-

32 R. Brubaker et al., Nationalist Politics...

33 A.D. Smith, National Identity..., p. 172; and S. Vertovec, Transnationalism...

34 A. Mintzel, Multikulturelle Gesellschaften in Europa und Nordamerika. Konzepte, Streitfragen, Analysen, Befunde, Passau 1997 (Makroanalyse und Gesellschaftsvergleich, 2); J. Maurais, M. Morris (eds.), Languages in a Globalising World, Cambridge 2005.

35 V. Ivanova, 'Language Politics and National Equality in Socialist Yugoslavia (1945-1974)' in L. Marácz, M. Rosello (eds.), Multilingual Europe..., pp. 81-111. 
spect to the Hungarian minorities in these states depended on various factors, such as size, reciprocal minorities, the relation of the state with the Hungarian minority and kin-state Hungary and so on. ${ }^{36}$ There is a pattern that the larger the size of the Hungarian minority, the more difficult it is for the minority to receive minority and language rights from the state these minorities live in. The Hungarians in Transylvania with around 1.5 million official speakers are certainly in a difficult position. The fact that they are the biggest minority group clearly plays a role in the discrimination of their language, as it is not treated as equal to the Romanian state language. Another factor that affects the rights of minorities and minority languages is whether there is a reciprocal minority of comparable size. This is the case between Hungary and Slovenia, where on both sides of the border there is a small reciprocal language minority enjoying minority and language rights that are equal to those of the national language of the state. ${ }^{37} \mathrm{~A}$ third factor that plays an important role in granting minority rights to Hungarian minority speakers is governed by the relation of the kin-state Hungary and the host country of the Hungarian minority. ${ }^{38}$ There is a tense structural relation between Slovakia and Hungary, causing pressure on the Hungarian minority in southern Slovakia. ${ }^{39}$ In turn, the tense situation in southern Slovakia affects the relations between Slovakia and Hungary.

In the grouping of the seven states discussed above two dividing lines appear. First of all, there is a nationalist versus non-nationalist multicultural language policy. It is worth noting that in the latter case the policy is "inclusive" if democratic rights and equality are granted to the speakers of minority languages as well. The only multicultural language policy in which the Hungarian language displays an equal position to all other languages, including the official state language, is the one of the autonomous province of Vojvodina in Serbia. Hence, the position of the minority languages in the Carpathian Macroregion, including the Hungarian language is the best in Vojvodina. This traditional region has become an autonomous province within Serbia. ${ }^{40}$ The statute of the Autonomous Province of Vojvodina was agreed upon by the Serbian Parliament on November 30, 2009, and afterwards was ratified in the Parliament of Vojvodina on December 14, 2009 and entered into force on January 1,2010. This statute defines the AP of Vojvodina as a multi-ethnic, multilingual and multicultural community. The Hungarian minority received the status of a national community equal to the Serbian majority

36 See also G. Sasse, G., EU Conditionality and Minority Rights. Translating the Copenhagen Criterion into Policy, San Domenicao (Fl) 2005, p. 13 (EUI Working Papers, 16).

37 A. Kolláth, 'A szlovéniai kisebbségek nyelvi jogai..., pp. 190-204.

38 B. Fowler, Fuzzing Citizenship, Nationalising Political Space: A Framework for Interpreting the Hungarian "Status Law" as a New Form of Kin-state Policy in Central and Eastern Europe, Brighton 2002 (Working Papers (ESRC Research Programme on One Europe or Several?), 40/02); Z. Kántor et al. (eds.), The Hungarian Status Law. Nation Building and/or Minority Protection, Sapporo 2004 (Slavic Eurasian Studies, 4); S. Gal, 'Hungarian..., pp. 207-232; and S. Deets, Networks and Composite States: Rethinking Minority Representation and Governance, Paper prepared for the International Studies Association Convention, 16 February 2010.

39 Z. Csergo, Talk of the Nation. Language and Conflict in Romania and Slovakia, Ithaca 2007.

40 I. Szilágyi, A vajdasági statútum történelmi, politikai elözményei, az elfogadás körülményei, Budapest 2009. 
community (see Article 25 of the Statute of the AP of Vojvodina). According to Article 26 (see Official Journal of the AP no. 17/09) the AP of Vojvodina recognizes six official languages, i.e. Serbian, Hungarian, Slovak, Romanian, Croatian, and Ruthenian. In this case, we can speak of a language policy of inclusion in a multicultural setting.

Within the domain of nationalist language policies, which is characterized by a hegemonic position of the state language, there is a further division between states with the nationalist language policies that are inclusive and states with the nationalist languages policies that are exclusive. Austria, Slovenia and Croatia belong to the former group, where a Hungarian language minority lives in specific regions, i.e. Burgenland, the Mura Region and the Pannonian/Slavonian part of Croatia, respectively. In these areas, the Hungarian language enjoys equality with the official state language, i.e. German in Austria, Slovenian in Slovenia and Croatian in Croatia. ${ }^{41}$ In these countries, although there exists a nationalist language policy supporting the official language without restrictions, minority languages have an official status in the areas where the Hungarian minorities are present. ${ }^{42}$

However, the situation is substantially different in Slovakia, Romania, and Ukraine, where, in legal terms, the Hungarian language is not equal to the official state languages, i.e. Slovak, Romanian, and Ukrainian respectively, not even in those territories where the ethnic Hungarians live and sometimes form a majority. ${ }^{43}$ This means that in these countries the Hungarian language and culture face restrictions in the administrative, educational, judicial and public domains. These states follow a policy of "exclusion", which is characterized by inequalities like hierarchies, subordination, asymmetries, additional provisions, anomalies, discrimination or language laws restricting the use of the minority languages or promoting the use of the official language discriminating against the Hungarian language in the official and public domain.

In sum, Table 4 presents the language policies of the states with Hungarian minorities in the Carpathian Macroregion:

Table 4. Language policies in the Carpathian Macroregion

\begin{tabular}{|c|c|c|}
\hline & Nationalist language policy & Multicultural Language Policy \\
\hline Policy of Inclusion & $\begin{array}{c}\text { Austria (Burgenland) } \\
\text { Slovenia (Mura Region) } \\
\text { Croatia (Slavonia) }\end{array}$ & Serbia (Vojvodina) \\
\hline Policy of Exclusion & $\begin{array}{c}\text { Slovakia } \\
\text { Romania (Transylvania) } \\
\text { Ukraine (Subcarpathia) }\end{array}$ & \\
\hline
\end{tabular}

Source: L. Marácz, 'Towards a European System Guaranteeing Linguistic Minority Rights Protection: Including the Hungarian Cases' in A. Alik (ed.), Concepts and Consequences of Multilingualism in Europe 2, Tetovo 2011.

\footnotetext{
$41 \quad$ O. Nádor, L. Szarka (eds.), Nyelvi jogok...

42 L. Szarka, 'Államnyelv..., pp. 15-37.

43 J. Péntek, 'Magyar nyelv..., pp. 267-273; and Z. Csergo, Talk of the Nation...
} 
Although the patterns of language policies are more or less fixed, the policies are clearly affected by the Europeanization of Central and Eastern Europe. In fact, the process of Europeanization covers two separate processes that are connected. ${ }^{44}$ First of all, there is the transfer of the European Union's acquis communautaire, i.e. the system of rules and regulations within the Union that is promoting democratic rights and the rule of law in the Central and Eastern European region. ${ }^{45}$ The extension of the rule of law also reaches countries that are not members of the Union but are in close proximity to the Union, like the Balkans. ${ }^{46}$ Organisations closely linked to the European Union, like the Council of Europe, are also promoting human and minority rights protection in this area. ${ }^{47}$ The second process induced by Europeanization is the widening of the European communicative space, which means that the borders are becoming porous, and in the countries of the European Union, multilingual and transnational communication is intensifying. Let us consider in more detail how Europeanization has affected the position of the Hungarian minority languages in the Carpathian Macroregion.

\section{EUROPEANIZATION OF CENTRAL AND EASTERN EUROPE}

The European Union has acknowledged that linguistic diversity will remain an essential feature of European culture. 48 "Europe" will become increasingly Babylonian due to urbanization, migration, globalization, and Europeanization itself. ${ }^{49}$ For technical and political reasons, the Union has not recognized an official language of communication. As the former commissioner for multilingualism Leonard Orban, ${ }^{50}$ puts it, In a Union where diversity is cherished, a lingua franca can never be enough to satisfy every communication need. In the resolution Multilingualism: an asset for Europe and a shared commit-

44 See A. Wiener, T. Diez, European Integration Theory, Oxford 2009; D. Dinan, Ever Closer Union. An Introduction to European Integration, Basingstoke 2010.

45 See G. Schwellnus, 'The Adoption of Nondiscrimination and Minority Protection Rules in Romania, Hungary, and Poland' in F. Schimmelfennig, U. Sedelmeier (eds.), The Europeanization of Central and Eastern Europe, Ithaca 2005, pp. 51-71 (Cornell Studies in Political Economy).

46 See I. Bache, S. George, S. Bulmer, Politics in the European Union, Oxford 2010.

47 Compare J. Skovgaard, Towards a European Norm? The Framing of the Hungarian Minorities in Romania and Slovakia by the Council of Europe, the EU and the OCSE, Florence 2007 (EUI Working Papers SPS, 7), p. 12; and L. Marácz, 'Language Policies in Central and East European States with Hungarian Minorities: Implications for Linguistic Rights Protection of National Minorities in the EU' in I. Horváth, M. Tonk (eds.), Minority Politics within the Europe of Regions, Cluj-Napoca 2011, pp. 155-185 (Workshop Series).

48 See G. Extra, D. Gorter, 'The Constellation of Languages in Europe: an Inclusive Approach' in iidem (eds.), Multilingual Europe..., pp. 3-63.

49 See R.J. Holton, Globalization and the Nation State, Basingstoke 2011; L. Marácz, 'Hybridity as a Characteristic Feature of Globalization' in J. Róka (ed.), Globalisation, Europeanization and Other Transnational Phenomena: Description, Analyses and Generalizations, Budapest 2011, pp. 14-31.

50 L. Orban, Is There a Future for Linguistic Diversity in Europe?, Speech delivered by European Commissioner for Multilingualism, 7 December 2009, at the University of Rennes, Rennes. 
ment, the European Union declares that Europe's linguistic diversity constitutes a major cultural asset and that it would be wrong for the European Union to restrict itself to a single main language ${ }^{51}$ (see Article 4).

$V$ olman ${ }^{52}$ argues that linguistic diversity is now anchored in the legal system of the EU. Policies of multilingualism will continue to develop, even if they meet with strong resistance from the Member States. ${ }^{53}$ According to him, Article 3 of the consolidated Treaty on European Union, the so-called "Lisbon Treaty", which describes the aims of the EU, stipulates amongst other things that the Union shall respect its rich cultural and linguistic diversity, and shall ensure that Europe's cultural heritage is safeguarded and enhanced. The provision mirrors Article 22 of the European Charter of Fundamental Rights (ECFR), which states that The Union respects cultural, religious and linguistic diversity. ${ }^{54}$ Volman stresses that these articles will be referred to by those who want a system that is even more multilingual. According to him, the enhancing of minority and regional languages has only just begun. Any attempt to use the new linguistic provisions of the Lisbon Treaty to influence the language policies in the Member States, for example those affecting linguistic minorities (both autochthonous minorities and migrant communities), will be considered in this context.

Apart from the 24 official languages of the European Union, around sixty indigenous, regional or minority languages are spoken on its territory..$^{55}$ Indigenous minority languages are the languages that are spoken by a minority community distinct from the majority constituting the state nation. Sometimes, these minority languages can be the official languages in the regions where they are spoken by the minority groups, as was discussed above in the case of the nationalist, exclusive language policies. No special European Union convention protects minority languages, although the right to use one's mother tongue is recognized as a fundamental right in the EU. ${ }^{56}$ The European Parliament has adopted several resolutions to protect minority rights, including language rights. ${ }^{57}$ Article 24 of the recent resolution Multilingualism: an asset for Europe and a shared commitment states that the Union Encourages and supports the introduction

51 This resolution has been adopted by the European Parliament on 24 March 2009.

52 Y. Volman, 'The Lisbon Treaty and Linguistic Diversity: Policy and Practice in the European Institutions' in L. Marácz, M. Rosello (eds.), Multilingual Europe...

53 See the studies of Will Kymlicka, especially: W. Kymlicka, Multicultural Citizenship. A Liberal Theory of Minority Rights, Oxford 1996 (Oxford Political Theory); W. Kymlicka, A. Patten (eds.), Language Rights and Political Theory, Oxford 2003; and W. Kymlicka, Multicultural Odysseys. Navigating the New International Politics of Diversity, Oxford 2007.

54 See Article 22 of the Charter of Fundamental Rights of the European Union concluded in Nice on December 7, 2000 which states that the Union shall respect cultural, religious and linguistic diversity.

55 G. Extra, D. Gorter (eds.), Multilingual Europe...

56 See B. Vizi, 'Az Európai Unió és a kisebbségi nyelvek' in O. Nádor, L. Szarka (eds.), Nyelvi jogok..., pp. 37-56.

57 In 1981, 1983, 1987, 1994, 1996, 1997 and 1998; M. Jutila, Minorities of European Orders: Evolution of Transnational Governance of Minority Rights in Europe, Paper Prepared for the ISA Annual Conference, New York, 15-18 February 2009; and S. Trifunovska (ed.), Minority Rights in Europe. European Minorities and Languages, The Hague 2001, pp. 145-147 (Minority Rights in Europe). 
of mother tongue minority, local and foreign languages on a non-compulsory basis within school programs and/or in the context of extracurricular activities open to the community. ${ }^{58}$ Article 26 from the same document states that the Union Reiterates its longstanding commitment to the promotion of language learning, multilingualism and linguistic diversity in the European Union, including regional and minority languages, as these are cultural assets that must be safeguarded and nurtured; considers that multilingualism is essential for effective communication and represents a means of facilitating comprehension between individuals and hence acceptance of diversity and of minorities. ${ }^{59}$

Even more robust policies in support of indigenous minority languages have been adopted by the Council of Europe. It is worth notingthat all the member states of the European Union are members of the Council of Europe too. However, the Council of Europe has no sanctioning mechanism, if these resolutions are not met. ${ }^{60}$ The Council of Europe formulated the most clear legal treaties to protect national minority languages: the Framework Convention for the Protection of National Minorities (FCPNM) signed in Strasbourg on February 1, 1995, and the European Charter for Regional or Minority Languages (ECRML) signed on November 5, 1992 also in Strasbourg. ${ }^{61}$ The Framework Convention supports the positive discrimination of national minorities on the basis of human rights and general freedom rights, and recognizes the fact that minority rights are group rights, and that cross-border cooperation is not only restricted to states, but local and regional authorities can also take part in it. The Language Charter has been motivated by similar considerations. Languages are part of a common cultural heritage and the protection of languages is necessary to counterbalance state policy of assimilation and uniformization stimulated by modern civilization. ${ }^{62}$ Note that all the Central and Eastern European states with Hungarian linguistic minorities have ratified these charters as well:

Table 5. Framework Convention (FCPNM, CETS no. 157)

\begin{tabular}{|c|c|c|c|}
\hline States & Signature & Ratification & Entry into Force \\
\hline Romania & $01 / 02 / 1995$ & $11 / 05 / 1995$ & $01 / 02 / 1998$ \\
\hline Serbia & $11 / 05 / 2001$ & $11 / 05 / 2001$ & $01 / 09 / 2001$ \\
\hline Slovakia & $01 / 02 / 1995$ & $14 / 09 / 1995$ & $01 / 02 / 1998$ \\
\hline Austria & $01 / 02 / 1995$ & $31 / 03 / 1998$ & $01 / 07 / 1998$ \\
\hline Croatia & $06 / 11 / 1996$ & $11 / 10 / 1997$ & $01 / 02 / 1998$ \\
\hline
\end{tabular}

58 See footnote 48.

59 See footnote 48.

60 L. Marácz, 'Language Policies..., pp. 155-185.

61 S. Trifunovska (ed.), Minority Rights..., pp. 145-147.

62 Consider R. Brubaker et al., Nationalist Politics...; L. Marácz, 'Will Hungarian Become..., pp. 117-141; idem, 'European Tools..., pp. 77-116; and idem, 'Multilingualism in the Hungarian Kingdom..., pp. 55-96. 


\begin{tabular}{|c|c|c|c|}
\hline States & Signature & Ratification & Entry into Force \\
\hline Slovenia & $01 / 02 / 1995$ & $25 / 03 / 1998$ & $01 / 07 / 1998$ \\
\hline Ukraine & $15 / 09 / 1995$ & $26 / 01 / 1998$ & $01 / 05 / 1998$ \\
\hline Hungary & $01 / 02 / 1995$ & $25 / 09 / 1995$ & $01 / 02 / 1998$ \\
\hline
\end{tabular}

Table 6. Language Charter (ECRML, CETS no. 148)

\begin{tabular}{|c|c|c|c|}
\hline States & Signature & Ratification & Entry into Force \\
\hline Romania & $17 / 07 / 1995$ & $24 / 10 / 2007$ & $01 / 05 / 2008$ \\
\hline Serbia & $22 / 03 / 2005$ & $15 / 02 / 2006$ & $01 / 06 / 2006$ \\
\hline Slovakia & $20 / 02 / 2001$ & $05 / 09 / 2001$ & $01 / 01 / 2002$ \\
\hline Austria & $05 / 11 / 1992$ & $28 / 06 / 2001$ & $01 / 10 / 2001$ \\
\hline Croatia & $05 / 11 / 1997$ & $05 / 11 / 1997$ & $01 / 03 / 1998$ \\
\hline Slovenia & $03 / 07 / 1997$ & $04 / 10 / 2000$ & $01 / 01 / 2001$ \\
\hline Ukraine & $02 / 05 / 1996$ & $19 / 09 / 2005$ & $01 / 01 / 2006$ \\
\hline Hungary & $05 / 11 / 1992$ & $26 / 04 / 1995$ & $01 / 03 / 1998$ \\
\hline
\end{tabular}

In principle, the Hungarian language communities all over the Carpathian Macroregion enjoy a modest legal protection due to these two conventions. These conventions provide protection for the speakers of Hungarian in the states where the Hungarian language is a minority language.$^{63}$ In the future, it should be possible to improve the norms and standards of minority rights protection, including language rights. However, as the legal implementation is a part of the language policy subject to the European Union's leverage, local political measures can and have neutralized the implementation of these language policies.

Hungarians in Slovakia and Romania are confronted with hierarchies and asymmetries. International agreements, like the FCPNM and ECRML, are violated by national legislation and practice as the completion of the Slovak Language Law no. $270 / 1995$ unambiguously demonstrates. This law promotes the language of the majority at the expense of the minority languages in Slovakia. Neither Slovakia nor Romania are urged to undertake special measures in order to promote the identity of their Hungarian minorities. Therefore, there is no effective policy against the assimilation in Slovakia and Romania. The use of the Hungarian language in education and all other areas of life is seen as a special right to be regulated by law. Language laws include special provisions in order to restrict the use of the Hungarian language, such as a threshold of at least twenty percent of ethnic Hungarians living in an administrative-territorial unit. Although the contact with other ethnic Hungarians from the Carpathian Macroregion in theory is unhindered, the Romanian and Slovak authorities often view these kinds

63 J. Skovgaard, Towards..., p. 12. 
of contacts as a threat to the state. The Slovak border police regularly control visitors from Hungary in the areas inhabited by the Hungarian minorities, although formally there should be no border control because both Hungary and Slovakia are members of the Schengen Agreement.

In sum, the legal situation created by the Europeanization of Central and Eastern Europe is favoring the position and the use of minority languages. Minority rights protection in the region, although still far from perfect, has improved. ${ }^{64}$ Its improvement owes much to the Union's leverage and its conditionality, but in some cases domestic politics drives the process and has worsened the situation. ${ }^{65}$ This is true for the ethnic Hungarian communities as well. They are allowed to speak Hungarian, open Hungarian schools and use the Hungarian language, yet in public space it is restrained. Ethnic Hungarians are able to organize themselves and to form political parties and other societal interest groups and organizations to raise their voice to protect the Hungarian language and culture, both in regional and national parliaments, as well as in the European Parliament. The position of minority languages is strengthened due to the general climate within the European Union and the support from other supranational forums, such as the Council of Europe or the United Nations cooperating with the Union in this respect. As a result, the nationalist language policies that were discussed in Table 4 are moderated by the Europeanization of the Central and Eastern European space. With the establishment of the Union, the role of the monolingual state has been reduced, and multilingual regions have been given opportunities to develop.

\section{CONCLUSIONS}

In this paper, I have argued that the position of the Hungarian minority languages in the New Europe has improved, due to universal human rights conventions and the norms and standards of Europeanization. However, it can still be hampered by the local politics of language policy. Hungarian is spoken in the Carpathian Macroregionas as a national, official language in Hungary, and as a minority language in the multilingual regions of the seven neighbouring states of Hungary, i.e. Slovakia, Ukraine (Subcarpathian region), Romania (Transylvania), Serbia (Vojvodina), Croatia (Pannonian/ Slavonian part), Slovenia (Mura Region), and Austria (Burgenland). Within a European framework, it is to be expected that multilingual and transnational communication will intensify in the Carpathian Macroregion. Hungarian and other national languages will function as a transnational regional vernacular language. Different language repertoires and communication modes are being developed to make multilingual and transnational communication easier and more effective. In these strategies, plurilingual speakers such as minority speakers are in a key position to demonstrate that their Hungarian minority variant has become more important.

\footnotetext{
64 Z. Kántor et al. (eds.), The Hungarian Status Law... 
The Hungarian minorities in the states they live in have been confronted, especially in the twentieth century, with a nationalist language policy favoring the official language of the state, i.e. the majority language. However, the discrimination of minority languages in the Union is not only a problem for the Hungarian minority speakers in the Carpathian Macroregion, but thethe nationalist language policies are losing their strength. There are several reasons for this. Due to all sorts of globalization effects, like Europeanization, the role of the nation-state becomes less prominent and borders become porous. The implementation and transfer of regimes of human and minority rights within the Union and to its periphery have strengthened the language rights of minority speakers. The Union is acting in concert in this field with other supranational organizations, like the Council of Europe and the United Nations. This has led to the implementation of minority rights protection conventions, like the Framework Convention for the Protection of National Minorities and the European Charter for Regional or Minority Languages. With the help of the Europeanization, a real multilingual language policy has recently been realized in Vojvodina and Kosovo, which might set some benchmarking for other multilingual regions in Central and Eastern Europe.${ }^{66}$ Although the intervention of the European Union in the language policy of the individual Member States remains a sensitive issue - language issues are closely related to the identity of the Member States - now the Union has the legal tools to make the protection of minority language rights more effective. ${ }^{67}$ However, at a local level the states still have the possibility to avoid the general implementation of universal conventions,norms and standards. Hence, to a great extent, language policies are very much dependent on local political decisions that might take different variables into account. As a result, a heterogeneous pattern of language regimes arises.

\section{BIBLIOGRAPHY}

Bache I., George S., Bulmer S., Politics in the European Union, Oxford 2010.

Batory A., 'Kin-state Identity in the European Context: Citizenship, Nationalism and Constitutionalism in Hungary', Nations and Nationalism, Vol. 16, No. 1 (2010), at <http://dx.doi. org/10.1111/j.1469-8129.2010.00433.x>.

Beregszászi A., Csernicskó I., 'A magyar nyelv használatának lehetőségei Kárpátalján de jure és de facto' in O. Nádor, L. Szarka (eds.), Nyelvi jogok, kisebbségek, nyelvpolitika Kelet-Közép-Európában, Budapest 2003 (Magyar Kisebbségi Könyvtár).

Bideleux R., Jeffries I., A History of Eastern Europe. Crisis and Change, London 1998. Bowman I., The New World. Problems in Political Geography, London 1923.

66 See C.M. Sarnyai, T. Pap, 'Personal Autonomy and/or National Councils in Vojvodina' in I. Horváth, M. Tonk (eds.), Minority Politics...

67 Compare Y. Volman, 'The Lisbon Treaty..., pp. 37-56; and B. Vizi, 'Minority Languages and Multilingualism in Europe and in the European Union' in L. Marácz, M. Rosello (eds.), Multilingual Europe..., p. 155. 
Brubaker R. et al., Nationalist Politics and Everyday Ethnicity in a Transylvanian Town, Princeton 2006.

Cadzow J.F., Ludanyi A., Elteto L.J. (eds.), Transylvania. The Roots of Ethnic Conflict, Kent 1983.

Chaszar E., 'Trianon and the Problem of National Minorities' in B.K. Király, P. Pastor, I. Sanders (eds.), Essays on World War I. Total War and Peacemaking, a Case Study on Trianon, New York 1982 (War and Society in East Central Europe, 6. East European Monographs, 105. Atlantic Studies, 15).

Csergo Z., Talk of the Nation. Language and Conflict in Romania and Slovakia, Ithaca 2007.

Deets S., Networks and Composite States: Rethinking Minority Representation and Governance, Paper prepared for the International Studies Association Convention, 16 February 2010.

Dinan D., Ever Closer Union. An Introduction to European Integration, Basingstoke 2010.

European Commission, Special Eurobarometer 243: Europeans and their languages, Brussels 2006, at <http://ec.europa.eu/public_opinion/archives/ebs/ebs_243_en.pdf>.

Extra G., Gorter D., 'The Constellation of Languages in Europe: an Inclusive Approach' in iidem (eds.), Multilingual Europe. Facts and Policies, Berlin 2008 (Contributions to the Sociology of Language, 96).

Extra G., Gorter D. (eds.), Multilingual Europe. Facts and Policies, Berlin 2008 (Contributions to the Sociology of Language, 96).

Fenyvesi A. (ed.), Hungarian Language Contact Outside Hungary. Studies on Hungarian as a Minority Language, Amsterdam 2005 (Impact: Studies in Language and Society, 20).

Fowler B., Fuzzing Citizenship, Nationalising Political Space: A Framework for Interpreting the Hungarian "Status Law" as a New Form of Kin-state Policy in Central and Eastern Europe, Brighton 2002 (Working Papers (ESRC Research Programme on One Europe or Several?), 40/02).

Gal S., 'Hungarian as a Minority Language' in G. Extra, D. Gorter (eds.), Multilingual Europe. Facts and Policies, Berlin 2008 (Contributions to the Sociology of Language, 96).

Gal S., 'Polyglot Nationalism. Alternative Perspectives on Language in $19^{\text {th }}$ Century Hungary', Langage et Société, Vol. 2, No. 136 (2011), at <http://dx.doi.org/10.3917/1s.136.0031>.

Goldstein E., The First World War Peace Settlements, 1919-1925, London 2002 (Seminar Studies in History).

Holton R.J., Globalization and the Nation State, Basingstoke 2011.

Hupchick D.P., Cox H.E., The Palgrave Concise Historical Atlas of Eastern Europe, New York 2001.

Ivanova V., 'Language Politics and National Equality in Socialist Yugoslavia (1945-1974)' in L. Marácz, M. Rosello (eds.), Multilingual Europe, Multilingual Europeans, Amsterdam 2012 (European Studies, 29).

Janssens R., Mamadouh V., Marácz L., 'Languages of Regional Communication (ReLan) in Europe: Three Case Studies and a Research Agenda' in J. Normann Jorgensen (ed.), A Toolkit for Transnational Communication in Europe, Copenhagen 2011 (Copenhagen Studies in Bilingualism, 64).

Jutila M., Minorities of European Orders: Evolution of Transnational Governance of Minority Rights in Europe, Paper Prepared for the ISA Annual Conference, New York, 15-18 February 2009. 
Kántor Z. et al. (eds.), The Hungarian Status Law. Nation Building and/or Minority Protection, Sapporo 2004 (Slavic Eurasian Studies, 4).

Kocsis K. (ed.), South Eastern Europe in Maps, Budapest 2005.

Kocsis K., Bottlik Z., Tátrai P., Etnikai térfolyamatok a Kárpát-medence határainkon túli régióiban (1989-2002), Budapest 2006 (Elmélet, Módszer, Gyakorlat, 61).

Kocsis K., Kocsis-Hodosi E., Hungarian Minorities in the Carpathian Basin. A Study in Ethnic Geography, Toronto-Buffalo 1995.

Kolláth A., 'A szlovéniai kisebbségek nyelvi jogai - különös tekintettel a magyar kisebbségre' in O. Nádor, L. Szarka (eds.), Nyelvi jogok, kisebbségek, nyelvpolitika Kelet-Közép-Európában, Budapest 2003 (Magyar Kisebbségi Könyvtár).

Kontra M., Hattyár H. (eds.), Magyarok és nyelvtörvények, Budapest 2002 (Magyarságkutatás Könyvtára, 26).

Korhecz T., 'A hivatalos nyelvhasználat jogi keretei a Vajdaságban - Szerbiában - jog és gyakorlat', Magyar Tudomány, Vol. 11 (2009).

Korshunova G., Marácz L., 'Multilingualism and Transnational Communication Strategies in Europe: From Hapsburg to the European Union' in L. Marácz, M. Rosello (eds.), Multilingual Europe, Multilingual Europeans, Amsterdam 2012 (European Studies, 29).

Kovács M.M., Tóth J., 'Kin-state Responsibility and Ethnic Citizenship: The Hungarian Case' in R. Bauböck et al. (eds.), Acquisition and Loss of Nationality, Vol. 1: Comparative Analyses, Amsterdam 2009 (IMISCOE Research).

Kymlicka W., Multicultural Citizenship. A Liberal Theory of Minority Rights, Oxford 1996 (Oxford Political Theory).

Kymlicka W., Multicultural Odysseys. Navigating the New International Politics of Diversity, Oxford 2007.

Kymlicka W., Patten A. (eds.), Language Rights and Political Theory, Oxford 2003.

Lábadi K., 'Nyelvtörvények, nyelvi jogok Horvátországban’ in O. Nádor, L. Szarka (eds.), Nyelvi jogok, kisebbségek, nyelvpolitika Kelet-Közép-Európában, Budapest 2003 (Magyar Kisebbségi Könyvtár).

Marácz L., 'European Tools of Conflict Management in Central European States with Hungarian Minorities', Kommunikáció, Média, Gazdaság, Vol. 8, No. 1 (2010).

Marácz L., 'Guarding the Hungarian Language and Identity in the New Europe: “The Nation Lives in Its Language"' in idem (ed.), Expanding European Unity. Central and Eastern Europe, Amsterdam 1999 (Yearbook of European Studies, 11).

Marácz L., 'Hybridity as a Characteristic Feature of Globalization' in J. Róka (ed.), Globalisation, Europeanization and Other Transnational Phenomena: Description, Analyses and Generalizations, Budapest 2011.

Marácz L., 'Language Policies in Central and East European States with Hungarian Minorities: Implications for Linguistic Rights Protection of National Minorities in the EU' in I. Horváth, M. Tonk (eds.), Minority Politics within the Europe of Regions, Cluj-Napoca 2011 (Workshop Series).

Marácz L., 'Multilingualism in the Hungarian Kingdom (1867-1918): Language Policy and Practice' in J. Róka (ed.), Concepts \& Consequences of Multilingualism in Europe, Budapest 2010 . 
Marácz L., 'Towards a European System Guaranteeing Linguistic Minority Rights Protection: Including the Hungarian Cases' in A. Alik (ed.), Concepts and Consequences of Multilingualism in Europe 2, Tetovo 2011.

Marácz L., 'Will Hungarian Become a Lingua Franca in the Carpathian Basin?' in B. Bodó, M. Tonk (eds.), European Union, Nations and National Minorities, Cluj-Napoca 2009.

Marácz L., Rosello M. (eds.), Multilingual Europe, Multilingual Europeans, Amsterdam 2012 (European Studies, 29).

Maurais J., Morris M. (eds.), Languages in a Globalising World, Cambridge 2005.

Mintzel A., Multikulturelle Gesellschaften in Europa und Nordamerika. Konzepte, Streitfragen, Analysen, Befunde, Passau 1997 (Makroanalyse und Gesellschaftsvergleich, 2).

Nádor O., Szarka L. (eds.), Nyelvi jogok, kisebbségek, nyelvpolitika Kelet-Közép-Európában, Budapest 2003 (Magyar Kisebbségi Könyvtár).

Orban L., Is There a Future for Linguistic Diversity in Europe?, Speech delivered by European Commissioner for Multilingualism, 7 December 2009, at the University of Rennes, Rennes. Péntek J., 'Magyar nyelv, magyar nyelvhasználat Kolozsváron' in A. Benő, S.N. Szilágyi (eds.), Nyelvi közösségek - nyelvi jogok, Kolozsvár 2006 (Szabó T. Attila Nyelvi Intézet Kiadványai, 3). Péntek J., Benő A., 'Nyelvi jogok Romániában' in O. Nádor, L. Szarka (eds.), Nyelvi jogok, kisebbségek, nyelvpolitika Kelet-Közép-Európában, Budapest 2003 (Magyar Kisebbségi Könyvtár).

Plank P.H. van der, Etnische zuivering in Midden-Europa. Natievorming en Staatsburgerschap in de XXe eeuw, Leeuwarden 2004 (Acta Launiana, 2).

Rindler Schjerve R. (ed.), Diglossia and Power. Language Policies and Practice in the $19^{\text {th }}$ Century Habsburg Empire, Berlin 2003 (Language, Power and Social Process, 9).

Rindler Schjerve R., Vetter E., European Multilingualism. Current Perspectives and Challenges, Bristol 2012 (Second Language Acquisition, 147).

Sarnyai C.M., Pap T., 'Personal Autonomy and/or National Councils in Vojvodina' in I. Horváth, M. Tonk (eds.), Minority Politics within the Europe of Regions, Cluj-Napoca 2011 (Workshop Series).

Sasse G., EU Conditionality and Minority Rights. Translating the Copenhagen Criterion into Policy, San Domenicao (Fl) 2005 (EUI Working Papers, 16).

Sasse G., 'The Politics of EU Conditionality: the Norm of Minority Protection during and beyond EU Accession', Journal of European Public Policy, Vol. 15, No. 6 (2008), at <http:// dx.doi.org/10.1080/13501760802196580>.

Schöpflin G., Hungary and its Neighbours, Paris 1993 (Chaillot Papers, 7).

Schwellnus G., 'The Adoption of Nondiscrimination and Minority Protection Rules in Romania, Hungary, and Poland' in F. Schimmelfennig, U. Sedelmeier (eds.), The Europeanization of Central and Eastern Europe, Ithaca 2005 (Cornell Studies in Political Economy).

Skovgaard J., Towards a European Norm? The Framing of the Hungarian Minorities in Romania and Slovakia by the Council of Europe, the EU and the OCSE, Florence 2007 (EUI Working Papers SPS, 7).

Smith A.D., National Identity, London 1991 (Penguin Politics and Current Affairs).

Szabómihály G., 'A szlovákiai kisebbségek nyelvi jogai és a kisebbségi nyelvhasználat színterei, különös tekintettel a magyar közösségre’ in O. Nádor, L. Szarka (eds.), Nyelvi jogok, kisebbségek, nyelvpolitika Kelet-Közép-Európában, Budapest 2003 (Magyar Kisebbségi Könyvtár). 
Szarka L., 'Államnyelv, hivatalos nyelv - kisebbségi jogok Kelet-Közép-Európában' in O. Nádor,

L. Szarka (eds.), Nyelvi jogok, kisebbségek, nyelvpolitika Kelet-Közép-Európában, Budapest 2003 (Magyar Kisebbségi Könyvtár).

Szilágyi I., A vajdasági statútum történelmi, politikai elözményei, az elfogadás körülményei, Budapest 2009.

Szoták S., 'Az ausztriai kisebbségek nyelvi jogai - különös tekintettel a magyar kisebbségekre' in O. Nádor, L. Szarka (eds.), Nyelvi jogok, kisebbségek, nyelvpolitika Kelet-Közép-Európában, Budapest 2003 (Magyar Kisebbségi Könyvtár).

Teleki P., The Evolution of Hungary and its Place in European History, New York 1923.

Tóth Á., National and Ethnic Minorities in Hungary, 1920-2001, trans. by N. Arato, Boulder 2005 (East European Monographs, 698. Atlantic Studies on Society in Change, 124).

Tóth J., 'Kin Minority, Kin-state and Neighbourhood Policy in the Enlarged Europe', Central European Political Science Review, No. 17 (2004).

Trifunovska S. (ed.), Minority Rights in Europe. European Minorities and Languages, The Hague 2001 (Minority Rights in Europe).

Vertovec S., Transnationalism, New York 2010 (Key Ideas).

Vizi B., 'Az Európai Unió és a kisebbségi nyelvek' in O. Nádor, L. Szarka (eds.), Nyelvi jogok, kisebbségek, nyelvpolitika Kelet-Közép-Európában, Budapest 2003 (Magyar Kisebbségi Könyvtár).

Vizi B., 'Minority Languages and Multilingualism in Europe and in the European Union' in L. Marácz, M. Rosello (eds.), Multilingual Europe, Multilingual Europeans, Amsterdam 2012 (European Studies, 29).

Volman Y., 'The Lisbon Treaty and Linguistic Diversity: Policy and Practice in the European Institutions' in L. Marácz, M. Rosello (eds.), Multilingual Europe, Multilingual Europeans, Amsterdam 2012 (European Studies, 29).

Wiener A., Diez T., European Integration Theory, Oxford 2009.

László MARÁCZ (PhD) is an Assistant Professor in the Department of European Studies at the University of Amsterdam. He studied general linguistics and Hungarian Studies at the University of Groningen. He publishes on the history of Eastern Europe, European multilingualism, the enlargement of the European Union in Central and Eastern Europe and on minority rights' protection. He coordinates a number of international projects, including a "Toolkit for Transnational Communication in Europe" sponsored by the Dutch Scientific Research Organization (NWO) and he is deputy coordinator of the MIME FP7 sponsored consortium on a multilingual Europe (www. mime-project.org). He is honorary professor of the L.N. Gumilyov Eurasian National University (Astana, Kazakhstan) and visiting professor of the Academy for Public Administration in Astana (Kazakhstan). 